\title{
Perception of Social Media in Secondary Students
}

\author{
Hatice Gedik ${ }^{1} \&$ Hamide Akbas Cosar ${ }^{2}$ \\ ${ }^{1}$ Aksaray University Faculty of Education, Department of Social Studies Education, Aksaray, Turkey \\ ${ }^{2}$ Graduate Degree in Social Studies Education (MA), Aksaray, Turkey \\ Correspondence: Hatice Gedik, Aksaray University Faculty of Education, Department of Social Studies \\ Education, Aksaray, Turkey. E-mail: htcgedik@gmail.com
}

Received: October 8, 2019

Accepted: November 25, 2019

Online Published: February 17, 2020

doi:10.5539/ies.v13n3p6

URL: https://doi.org/10.5539/ies.v13n3p6

\begin{abstract}
Communication has always been a basic need for human beings throughout the history. The Internet, which became widespread in the late 20th century, provided new and improved opportunities in communication. Social media, one of these communication opportunities, has become an indispensable means of communication. The aim of the current research is to determine which social media accounts the middle school students use and why they use social media. The sampling of the study is comprised of 211 students attending a state middle school in Turkey. In the current study, the participating students were asked to write an authentic composition with the title "use of social media" and the collected data in this way were analyzed by using the content analysis method. According to the results obtained in the current study, it can be argued that the participating children are aware of the negative effects of the use of social media on their social life, academic achievement and health. However, despite these negative effects, they find it difficult to keep themselves away from social media. According to the participating students, social media is a harmful communication tool that makes it easy to get information and news, is entertaining, addictive and not suitable for children.
\end{abstract}

Keywords: social media accounts, perception of social media

\section{Introduction}

\subsection{Introduce the Problem}

Communication is a mutual exchange of information and news. Communication has always been a basic need for human beings throughout the history. Communication is a reciprocal exchange occurring due to people's desire to learn what others know and to convey what they know to others (Crowley \& Heyer, 2014, p. 18). Through this reciprocal exchange, human beings have increased their knowledge and skills and thus they have been able to enhance their living standards. Humanity has expanded its area of communication by producing means of communication (Crowley \& Heyer, 2014, p. 19). The computer is one of the most important technological tools of our age (Yüksel, 2017). The expansion in the computer's area of usage has resulted in the widespread use of the Internet and the emergence of new ways of communication. The use of video chat and social media have provided new opportunities in many parts of our life yet also caused some problems. The Internet means a general network in short (URL 1). The Internet is a tool that allows users to access text, images, sounds, games and other data on the web page (Ersöz \& Seden-Meral, 2011). The most important feature of the internet broadcasting, one of the revolutionary developments in communication technology, is its being the most effective means of expressing and disseminating thoughts (Kalsin, 2014, p. 185).

\subsection{Explore Importance of the Problem}

As with all technological developments, military purposes have been effective in the emergence of the Internet. The Internet, which was used for experimental purposes in the early periods, developed with the computer network (ARPA-NET), which was established by the US Department of Defense for military purposes in the 1970s. The Internet, which continued to be used in the field of communication of the military in the 1980s, gained greater importance with its commercial dimension and became a virtual network that was used all over the world in the 1990s (Bulut, 2006, cited in Kırık, 2014, p. 274). The Internet, which was used as an electronic service in the 1970 s, accelerated the communication of the messages to the other side and increased the possibility of communication. In the 1980s, internet users were able to interact with each other. In 1988, instant messaging became possible. The Internet, which was born for military purposes in the 1990s, spread all over the world and 
WWW (World Wide Web) emerged (Kır1k, 2014, p. 281). Thus, the use of internet has spread across the world and has reached 3.77 billion users today.

A new internet application, known as the World Wide Web was created by Tim Berners-Lee and his colleagues, who was known as the father of the Internet and working in the CERN in 1990 (Crowley \& Heyer, 2014, p. 476).

Numerical values related to social networks are quite striking (Lenhart \& Madden, 2007, p. 2, cited in Dikme, 2013 , p. 8) of the university students, $82 \%$ are using social networks and $55 \%$ of the young people aged 19 years old or under are using social networks. Of the Internet users, $48 \%$ use the video sharing sites such as YouTube. According to a video broadcast in YouTube, the most popular social network in our country is Facebook. It is followed by Twitter (Dikme, 2013, p. 27).

With the Internet spreading all over the world, people's possibility of having access to social networking sites has increased. Web 1.0 technology that emerged between 1993 and 2013 was used for reading and research purposes only. With the introduction of Web 2.0 technology in 2004, Internet users had the opportunity to write, send and publish content without needing for any special software. The introduction of Web 2.0 technology has enabled users to be more free and active in network communication (Laughey, 2010, cited in Değirmencioğlu, 2014, p. 151). Web 2.0 technology is the system in which people contribute to the offered contents by making production rather than being a reader (Karadoğan-Doruk, Çavdar, \& Okumuş, 2014, p. 219).

According to the data issued by the Turkish Institute of Statistics (URL 2), the rate of individuals using the Internet in our country has reached $66.8 \%$ of the whole population. The rates of computer and Internet users in the age group 16-74 in 2017 were found to be $56.6 \%$ and $66.8 \%$, respectively. When compared to the rates in 2016 , these rates represent $1.7 \%$ and $5.7 \%$ increases, respectively. As can be seen from the data, the increase in the Internet use is greater. While the rates of computer and Internet users among the males aged 16-74 years old were found to be $65.7 \%$ and $75.1 \%$, respectively, they were 47.75 and $58.7 \%$ for the female users in the same age group. The rate of male computer and Internet users is higher than that of female users. Moreover, 8 out of every ten houses in our country have internet access. According to the results of the household information technologies usage research, 80.7\% of the households in Turkey had home Internet connection in April 2017 with the development of Web 2.0 technologies that prioritize social interaction, collaboration and sharing, different internet environments have been used today. Although it is possible to list these environments as blogs, microblogs, content sharing sites, social networks, all these Web 2.0 components are generally defined as social media (Argin, 2013). Social Media is a common term used for online tools and websites that allow mutual interaction by enabling users to share information, thoughts, interests and feelings (Sayımer, 2008, p. 123, cited in Solmaz et al., 2013).

In 1997, a historical step was taken for social media. The first social network Six Degrees, was established this year. In addition, the number of these social networks increased towards the 2000s (Kırık, 2014, p. 281). Social media, an internet-based communication with no time and space limitations (Karadoğan-Doruk, Çavdar, \& Okumuş, 2014, p. 213), can bring together individuals who are at different points in time and space in a virtual environment (Kırık, 2014, p. 281).

According to Büyükşener (2009), social networks and social media which are becoming more and more widespread via the web 2.0 movement, which transforms the Internet to a sharing environment, hold an incredible potential with the unprecedented opportunities it offers for communication and interaction.

\subsection{Describe Relevant Scholarship}

Social media has created a large universe by gathering all the people and institutions that can react to an unwanted event regardless of where it occurs in the world and all the people who can think and express what they think at anytime and anywhere in the world. According to Altunbaş (2014), social media has begun to replace traditional media with new opportunities it offers. According to the Global Digital (URL 3) report, which operates globally, the world's population is 7.476 million people. A total of 2.789 people making up $37 \%$ of the world population are active social media users. According to the same report, the use of social media increased $21 \%$ in 2017 when compared to 2016. The most preferred social media platform worldwide is Facebook with 305.9 million users. The percentage of males using Facebook (53\%) is higher than that of females $(47 \%)$.

The Turkish statistics issued in the same report showed that the population of Turkey is 80.02 million. Of this population, 48 million people (60\%) are Internet and social media users. Facebook is the most widely used social media platform in the world. In our country, Youtube is the most preferred social media platform with $57 \%$, while Facebook comes in second (56\%) and Tumblr is the least preferred (19\%) social media platform (URL 4).

According to Gürültü (2016), individuals who use the Internet intensively spend most of their time in these social media sites. The diversity of the channels offered by these social pages creates a center of attraction for every 
segment, from children to adults, and due to great interest they feel, especially children and young people directly and unconsciously receive what is presented to them in these social networking sites without having a change to select; thus, they are affected more negatively. The fact that many social media environments are free and each person can participate in these environments has popularized social media. Social media is not just a tool that allows individuals to communicate with their friends. Many organizations, businesses and institutions have recognized the benefits of these sites to the community and have been involved in the social media world (Altunbaş, 2014, p. 53).

Numerical values related to social networks are quite striking (Lenhart \& Madden, 2007, p. 2, cited in Dikme, 2013 , p. 8 ) of the university students, $82 \%$ are using social networks and $55 \%$ of the young people aged 19 years old or under are using social networks. Of the Internet users, $48 \%$ use the video sharing sites such as YouTube. According to a video broadcast in YouTube, the most popular social network in our country is Facebook. It is followed by Twitter (Dikme, 2013, p. 27).

Social media is one of the applications most widely used in our country in the Internet environment (Dikme, 2013, p. 124). However, research on social media mostly focuses on undergraduate students, adults and educators. The number of studies looking at middle school and high school students is very small (Şişman-Eren, 2014, p. 232).

\subsection{The Aim of the Study}

The age of using social media is continuously decreasing; thus, conducting research on middle school students seems to be of great importance. Therefore, the purpose of the current study is to determine secondary school students' opinions about the use of social media.

Problem: How do secondary schools' students perceive social media?

Sub-Problems:

- Which social media accounts do secondary school students prefer to use?

- What is the frequency of secondary school students using social media?

- What are the reasons why secondary school students prefer to use social media?

- What are the opinions of secondary school students about social media?

\section{Method}

In this section, the research method, participants, data collection process, and data analysis are discussed.

\subsection{Identify Subsections}

For this study, a qualitative research model was employed. Qualitative research is a method that uses qualitative data collection methods including observations, interviews, and document analysis and that follows a qualitative process to present perceptions and events in a realistic and holistic manner in the natural environment (Yildirım \& Şimşek, 2000). In this study, screening model which is one of the qualitative research methods was adopted. Screening models are research methods that aim to present the situation as it is (Karasar, 2007). In this section, the research method, participants, data collection process, and data analysis are discussed.

\subsection{Participants}

The study group of the current research is comprised of 211 middle school students attending a state middle school in the Turkey in the spring term of 2016-2017 school year. Of these 211 students, 103 are female and 108 are male.

\subsection{Data Collection Process}

Before collecting the data for the current research, the students were informed about the purpose of the study. The participants weren't asked no question directly related to social media. The participating middle school students were asked to write an original composition about "the use of social media" and the data collected in this way were subjected to the content analysis.

\subsection{Data Analysis}

Content analysis was used in the analysis and interpretation of the data. Content analysis is one of the most important techniques frequently used in social studies and can be defined as a systematic application in which text is summarized in smaller content categories with coding based on certain rules (Büyüköztürk, 2011). Qualitative data are described as identifying, counting, and interpreting repetitive subjects, problems, and concepts (Miles \& Huberman, 1994). The data were examined by two researchers individually and categories were identified. These categories were then discussed and agreed to give similar theme names to the same phenomenon. Miles and Huberman's (1994) formula was used for the reliability calculation of data. The reliability coefficient was 
calculated as 0.89 . The findings of the study are based on the consensus between the researchers.

\section{Results}

In this section, findings based on the data obtained from the participants are discussed.

While the results of the current study aiming to determine the middle school students' opinions about the use of social media are examined, it is first attempted to reveal the participating students' state of using social media.

The participants explained their reasons for using or not using social media. They expressed some positive and negative opinions about the use of social media. They also stated their suggestions to make social media a more secure environment for children.

\subsection{Statistics and Data Analysis}

Table 1. Categories created from collected data

\begin{tabular}{ll}
\hline Categories & Sub-categories \\
\hline $\begin{array}{l}\text { Social media usage status of } \\
\text { secondary school students }\end{array}$ & $\begin{array}{l}\text { Users } \\
\text { Nonusers }\end{array}$ \\
\hline Social media accounts in use & $\begin{array}{l}\text { Facebook, Messenger, Instagram, WhatsApp } \\
\text { Twitter, WattPad, Snapchat, Youtube }\end{array}$ \\
\hline \multirow{2}{*}{ Frequency of use in social media. } & $\begin{array}{l}\text { Everyday } \\
\text { Weekend } \\
\text { On long holidays }\end{array}$ \\
\hline \multirow{2}{*}{ Social media usage purposes } & $\begin{array}{l}\text { Course, entertainment, games, communication, spend time, to follow the things female/male loves and } \\
\text { people, sharing, obtain information, be aware of events, watching video. }\end{array}$ \\
\hline \multirow{3}{*}{ Opinions about social media } & $\begin{array}{l}\text { Positive } \\
\text { Negative } \\
\text { Suggestions }\end{array}$ \\
\hline
\end{tabular}

According to the content analysis after receiving expert opinions, the categories and sub-categories derived from the compositions written by the students are as follows: "the state of using social media, the social media accounts used, the frequency of social media use, the purposes for which social media is used, the students' opinions about social media.

Table 2. Participants using social media

\begin{tabular}{ccccl}
\hline & & Female & Male & Total \\
\cline { 2 - 5 } & & $\mathrm{f}$ & $\mathrm{f}$ & $\mathrm{F}$ \\
\hline \multirow{3}{*}{ Grade } & 5 & 25 & 25 & 50 \\
Level & 7 & 32 & 12 & 21 \\
& 8 & 7 & 14 & 21 \\
\hline Total & & 73 & 93 & 166 \\
\hline
\end{tabular}

166 participants $(79 \%)$ are stated that they used social media. As can be seen in Table 2, the highest percentage of social media use belongs to the seventh graders (45\%). The lowest percentage of social media use belongs to sixth $(13 \%)$ and eighth graders (13\%).

\subsection{Findings Related to the First Sub-Problem}

In Table 3, the participants' percentages of using social media accounts are presented. As can be seen in this table, the social media account having the highest percentage of usage is Facebook with 37\%. More than half of the participants using social media use Facebook. The students most frequently using YouTube, which is one of the most widely preferred social media accounts in the world (Lenhart \& Madden, 2007, p. 2, cited in Dikme, 2013, p. 8 ) are seventh graders. Wattpad is the least frequently used social media account with $9 \%$. Wattpad having the smallest percentage of usage is most frequently used by the fifth graders. One of the social media accounts, Messenger is not used by seventh and eighth graders and mostly preferred by the fifth and sixth graders. The participants stated that they use YouTube to watch entertaining videos and to study. 
Table 3. Participants' social media accounts

\begin{tabular}{rccccccc}
\hline & \multicolumn{5}{c}{ Grade level } & \multirow{2}{*}{ Total } \\
\cline { 3 - 6 } & & 5 & 6 & 7 & 8 & \\
\cline { 3 - 6 } & & $\mathrm{f}$ & $\mathrm{f}$ & $\mathrm{f}$ & $\mathrm{f}$ & $\mathrm{f}$ \\
\hline \multirow{5}{*}{ Social media accounts in use } & Facebook & 38 & 16 & 15 & 10 & 95 \\
& Instagram & 35 & 15 & 13 & 7 & 70 \\
& YouTube & 18 & 10 & 15 & 5 & 48 \\
& Messenger & 15 & 9 & 12 & 8 & 44 \\
& WhatsApp & 24 & 7 & 8 & 3 & 42 \\
& Snapchat & 16 & 5 & 4 & 3 & 28 \\
& Twitter & 12 & 3 & 3 & 4 & 22 \\
& Wattpad & 6 & 3 & 4 & 2 & 15 \\
\hline
\end{tabular}

The most popular reason stated for the use of Facebook is to communicate with families and beloved ones. Particularly those who have split families feel stronger need to communicate. The other reasons stated include finding and communicating with old friends, making new friends and flirting. The participants using Facebook the most frequently are the fifth graders. Participants are generally using Instagram for entertainment purposes. The reasons for the use of Youtube by participants are entertainment and homework study. They are use of Messenger for the communication purposes. Participants are use of WhatsApp for communicate, Snapchat for entertainment, Twitter to track events and individuals, Wattpad to read books and buy books.

\subsection{Findings Related to the Second Sub-Problem}

Table 4. Participants' social media usage frequency

\begin{tabular}{|c|c|c|c|c|c|c|c|}
\hline & & & \multicolumn{4}{|c|}{ Class Level } & \multirow{2}{*}{ Total } \\
\hline & & & 5 & 6 & 7 & 8 & \\
\hline & & & $\mathrm{f}$ & $\mathrm{f}$ & $\mathrm{f}$ & $f$ & $f$ \\
\hline \multirow{2}{*}{ Everyday } & Female & & 8 & 5 & 13 & 3 & 29 \\
\hline & Male & & 10 & 7 & 15 & 5 & 37 \\
\hline \multirow{2}{*}{ Weekend } & Female & & - & - & 12 & 3 & 15 \\
\hline & Male & & - & - & 8 & - & 8 \\
\hline \multirow{2}{*}{ On long holidays } & Female & & - & - & 10 & - & 10 \\
\hline & Male & & - & - & 8 & 3 & 11 \\
\hline Total & & $\mathrm{f}$ & 18 & 12 & 66 & 14 & 110 \\
\hline
\end{tabular}

In Table 4, the social media usage frequencies of the participants using social media are given. Only $52 \%$ (110 participants) of the participants mentioned their frequencies of social media usage. As can be seen in Table, only $31 \%$ (66 participants) of the participants use social media every day. Most of the students using social media every day are seventh graders.

\subsection{Findings Related to the Third Sub-Problem}

Participants, stated more than one reason to prefer social media. As seen in Table 5, the most important reason for the participants to use social media is to have fun and spend time (fun 67 , spend time 44 , game 35 , to watch video 23). 93 participants stated that they used social media to communicate with their family members and friends. More than half of the participants (communication 64 person. studying 43 person, to learn the news 25 person) stated that they use social media for education and information. As can be seen in Table 5, more than half of the participants using social media use social media for fun. Again, more than half of them use social media to communicate with their family members and friends. Nearly half of the participants stated that they use social media to study. Moreover, nearly half of the participants use social media to learn the news and to play games. Some participants stated that they use social media to share photographs and videos. Very few participants stated that they use social media to express their ideas. The participants generally use social media to have fun, to communicate, to learn something, to spend time and to study. Very few of them use it to share their ideas. 
Table 5. Purposes of participants' social media use

\begin{tabular}{lc}
\hline Purposes & $\mathrm{F}$ \\
\hline Fun & 67 \\
Communication & 64 \\
Information & 49 \\
Spend time & 44 \\
Studying & 43 \\
Game & 35 \\
To follow their loved ones & 29 \\
To follow their loved topics & 28 \\
To learn the news & 25 \\
To watch video & 23 \\
Sharing & 12 \\
To declare ideas & 4 \\
\hline
\end{tabular}

Seven of the participants stated that they started to use social media to study but then they started to waste their time in social media and ignore their studies. One of the participants expressed his/her reason for using social media as follows; "I use it to earn money and to be a phenomenon; in addition I can satisfy some of my feelings through social media."

\subsection{Findings Related to the Fourth Sub-Problem}

Nearly $97 \%$ of the participating students mentioned their opinions about social media. As can be seen in Table 6 , the highest percentage of positive opinions about social media are expressed by the sixth graders. When the students' opinions in relation to the gender variable were examined, it was found that $17 \%$ of the female and $30 \%$ of the males expressed positive opinions about social media. Thus, it can be argued that males have more positive opinions about social media than female. This is parallel to the use of social media because the participating boys use social media $(51.1 \%)$ more than the participating female (48.8\%). Thus, it seems that the boys' having more positive opinions about social media increased their rate of social media use.

Table 6. Participants' opinions about social media

\begin{tabular}{|c|c|c|c|c|c|c|}
\hline & & \multicolumn{4}{|c|}{ Class Level } & \multirow{2}{*}{ Total } \\
\hline & & 5 & 6 & 7 & 8 & \\
\hline & & $\mathrm{F}$ & $\mathrm{f}$ & $\mathrm{f}$ & $\mathrm{f}$ & $\mathrm{f}$ \\
\hline \multirow{2}{*}{ Positive opinion } & Female & 18 & 6 & 11 & 3 & 38 \\
\hline & Male & 19 & 14 & 29 & 4 & 63 \\
\hline \multirow{2}{*}{ Negative opinion } & Female & 12 & 6 & 13 & 4 & 35 \\
\hline & Male & 8 & 2 & 6 & 6 & 22 \\
\hline \multirow{2}{*}{ Positive and negative opinion } & Female & 6 & 3 & 18 & 3 & 30 \\
\hline & Male & 2 & 0 & 12 & 7 & 21 \\
\hline Total & & 62 & 31 & 89 & 27 & 205 \\
\hline
\end{tabular}

101 participants (48\%) have positive thoughts about social media. 57 participants $(27 \%)$ have negative thoughts about social media. 51 participants (24\%) expressed both positive and negative opinions about social media. 
Table 7. Examples from student opinions about social media

\begin{tabular}{|c|c|c|}
\hline Categories & Sub-Categories & $\mathrm{f}$ \\
\hline \multirow{8}{*}{$\begin{array}{l}\text { Positive opinions about social } \\
\text { media }\end{array}$} & I use social media to learn things I don't know & 47 \\
\hline & I use social media to watch funny and fun videos. & 23 \\
\hline & I use social media to be aware of events and people. & 22 \\
\hline & Social media is all over our lives. & 20 \\
\hline & I'm addicted to social media. I can't leave. & 17 \\
\hline & Social media is a very necessary application. & 43 \\
\hline & Most people use of social media & 16 \\
\hline & Without social media, we'd be bored & 13 \\
\hline \multirow{14}{*}{$\begin{array}{l}\text { Negative opinions about social } \\
\text { media }\end{array}$} & Social media is harmful. & 78 \\
\hline & Social media makes people addicted. & 57 \\
\hline & People use social media for evil purposes. & 48 \\
\hline & Social media is not a suitable app for children. & 45 \\
\hline & There are inappropriate content on social media. & 29 \\
\hline & Social media environment is bad. & 23 \\
\hline & Social media directs people to empty information. & 22 \\
\hline & Social media prevents people from establishing social relationships in real life. & 22 \\
\hline & Social media is a waste of time. & 21 \\
\hline & There are slang containing and abusive speeches in social media. & 19 \\
\hline & Social media use adversely affects human health. & 18 \\
\hline & People we don't know on social media want to communicate with us. & 16 \\
\hline & We postpone our studies because of social media. & 13 \\
\hline & I don't use social media because I think it will affect my lessons negatively. & 11 \\
\hline \multirow{6}{*}{$\begin{array}{l}\text { The recommendations about social } \\
\text { media }\end{array}$} & Most people use social media. A solution to this problem should be found. & 29 \\
\hline & Use of social media should be limited. & 27 \\
\hline & Instead of spending time on social media, it is better to study. & 15 \\
\hline & $\begin{array}{l}\text { People share all their information and photos on social media. This can be dangerous for } \\
\text { them. }\end{array}$ & 11 \\
\hline & We need to consciously use social media. & 5 \\
\hline & $\begin{array}{l}\text { On social media, they can open fake accounts on your behalf. They can share somethings } \\
\text { on your behalf. }\end{array}$ & 5 \\
\hline
\end{tabular}

Direct excerpts from students' opinions about social media, as follows:

- Examples of positive student opinions on about social media are given below:

Social Media is a very necessary application (P44).

Thanks to social media, we can reach everything we want (P67).

Social media is everywhere in our lives (P206).

Social media is a nice application that is very necessary, we have a lot of fun while using social media (P72).

Thanks to social media, people can easily access to everything information they want (P138).

- Examples of negative student opinions on about social media are given below:

Social media is preventing me from studying (P194).

In social media, some people using slang and abusive phrases (P8).

Social media is a waste of time (P184).

Some people use social media for bad purposes (P111).

Social media makes person addicted (P116).

Social media prevents people from having social relationships in real life (P29).

Because of social media, we postpone our work (P193).

It gives me, more pleasure to play on the street than to spend time on social media (P146). 
People who are addicted to social media change their lives according to social media. (P1).

Excessive use of social media causes waste of time and is addictive. Since we spend our time on social media, we are starting to postpone our important works. So, we should not make social media addictive. I became addicted to social media. (P19).

Social media is like an addictive substance. But it is an addiction with benefits. If we use social media too much, it is addictive. (P20).

I start using social media to study, but then I spend time on social media instead of studying (P36).

Social media is negative affecting communication with people. (P37).

Because of social media, people have problems in establishing social relationships in real life. That's why social relations are badly affected. (P27).

Because of social media, the face to face communication between people in the future, will be completely finished and people will only communicate in virtual area. (P21).

Social media is the worst thing. I don't like it at all. Social media is addictive. Humans may eliminate this addiction or may be more dependent. (P30).

Social media is a beautiful technology. But it block to our works. I know that. We're addicted, and I know that. We can hurt us, postpone our jobs and then accumulate our jobs. (P28).

Some people on social media, you can open fake accounts on your behalf, they can share on your behalf (P71).

Social media friendship area is bad and I don't use it because I don't like it. I don't have any social media accounts. In developed countries, we can see how little social media use. But when we look at our country, we can deduce that everyone is very fond of social media. I think that's a big problem. Developed countries, do not use their own social media applications very much, but in our country, social media sites are overused. This is a big problem (P100).

On social media, people don't care about each other's opinions and often make propaganda. To personal values and to cultures are being blasphemed, slang and blasphemous conversations are happening, which I do not like. People share everything, share their private information, many more things like pictures and videos. This, which can be a threat to them. Social media is not a safe place and should be made more secure. (P109).

I use social media only for studying. In my opinion, social media should not be used outside of homework study. Because it affects students' lessons badly. (P132).

I don't use social media because it is not suitable application for my age. I find social media dangerous especially for children. I don't intend to use social media until I grow up. In particular, children should use social media under the supervision of their parents and a restriction should be imposed. Social media should not be limitless because it is a dangerous. (P150).

I don't use social media, because I'm still a middle school student and I don't think social media is good for my classes. Also, as I have seen from my father and other acquaintances, social media is addictive. In my opinion, social media contains many things a children should not see, so the use of social media is not suitable for children. In addition, many bad people can deceive children through social media. In my opinion, especially children should use social media under family supervision, and only people over 18 should use social media. (P161).

Instead of social media, we should take time to study. This would be more beneficial for us. (P38).

In my opinion, social media is useful. There are some bad aspects. People's social media accounts can be stolen, unpleasant things can be shared, and this can get people into trouble. People we don't know on social media are trying to communicate with us. Social media is a dangerous area. We need to use it carefully. It can make people addicted, so there should be no unlimited use. (P31).

- Student opinions about social media in the form of suggestions:

People share all their information and photos on social media, this is dangerous for them. (P35).

A restriction should be imposed on social media or should be completely closed (P207).

Social media is addictive and wastes people's time. People can go to cinema or theater instead of spending time on social media. Children can play with friends on the street instead of playing on social media. I think that the use of social media should be reduced, then it will be more useful (P26). 
I take care not to enter bad sites on social media. Because, while browsing social media, sites that we are not interested and unfit to us can appear immediately, we must pay attention to this. In fact, social media is not suitable for children. In fact, social media is not suitable for children, so it should be restricted. (P152).

I don't use social media, but I think if I use it, it will adversely affect my classes. I would like to become a member to educational social media network, but I think that social networks that negative affect my works about homework's should be used after a certain age limit. There are sites that are not suitable for children in these applications, even when playing inappropriate sites may appear. Therefore, social media should be limited. I hope the number of thinking people like me will increase and limitation will be brought (P165).

In social media, people don't care about other people opinions, they usually make propaganda. Personal values and cultures are not respecting. Slang and blasphemous conversations are happening, which I do not like. People sharing everything, they share their private information, pictures and video, and so on. Social media is not a safe place and should be made more secure. (P109).

I don't use social media, other than studying. I think social media, should not be used outside the studying. Because it affects students' lessons badly. (P132).

I don't use social media. Not suitable for children my age. I find social media dangerous especially for children. I don't intend to use social media until I grow up. Children should use social media under the supervision of their parents. Or a restriction should be imposed as a limitation. Social media should not be unlimited, because it is a dangerous area. (P150).

In my opinion, social media is useful. There are some bad aspects. People's social media accounts can be stolen, unpleasant things can be shared, and this can get people into trouble. People we don't know on social media are trying to communicate with us. Social media is a dangerous area. We need to use it carefully. It can make people addicted, so there should be no unlimited use. (P31).

Some of the participants think that social media is a very useful application needed in every part of life, needed to have a good time, to learn what is happening and to communicate. Some other participants think that social media is a harmful application having some negative contents, including disrespectful remarks, deteriorating morality and preventing studying. According to the participants, excessive use of social media is a serious problem. It should be used carefully and limited.

\section{Discussion}

166 of 211 participants $(78.67 \%)$ stated that they use social media. The students using social media show some diversity depending on their gender and grade level. The findings revealed that the male students use social media more than the female students. Şişman-Eren $(2014$, p. 239) pointed out that the boys use social media more than the female for communicative purposes. This finding concurs with the findings of the current study. In a study conducted by Argin (2013) on middle school and high school students, no significant difference was found between the attitudes of boys and female towards social media. This finding is different from the finding of the current study. When the use of social media was examined depending on the grade level variable, it was found that the highest percentage of media use belongs to the fifth and seventh graders while the lowest percentage of social media use belongs to the sixth and eighth graders. The reasons stated by the students not using social media for not using it is its preventing studying, their concern about failure in TEOG exam, it's not being suitable for their age, unsuitable contents, bad sharing and its addictive nature.

The social media accounts preferred by the students are Facebook, Messenger, Instagram, WhatsApp, Twitter, WattPad, Snapchat and YouTube. Facebook, used by 79 participants (37\%), has become the most preferred social media account. In a study by Dikme (2013), it was found that the social media account most used by the participants (78 out of 103) is Facebook. According to 2019 data, Youtube is the most active social media platform ( $92 \%$ of the population). Instagram (84\%) and Facebook (83\%) follow him immediately (URL 5). It is followed by Facebook (53\%).In the current study, the social media account most preferred by the students is Facebook having the highest number of users in the world. Moreover, in a study by Dikme (2013, p. 126), it was also found that the most preferred social media account is Facebook. This finding concurs with the findings of the current study.

Of the participating students, $31 \%$ stated that they use social media every day. The participants' state of use varies depending on the gender and grade level variable. According to the findings, the seventh graders' frequency of using social media is higher than those of the other students. According to the results reported by Oğuz and Sözcü (2016), $76.5 \%$ of the pre-service teachers use social networks every day. This proves that social media has an important place in daily life.

The reasons stated by the participants for their use of social media are as follows; curiosity, communicating with 
their friends and beloved ones, making new friends, spending their free time, playing games and studying. Nearly half of the participants stated that they use social media to learn and study. The participants of the study conducted by Bayraktar (2013) stated they mostly use social media to play games. In a study by Eren et al. (2014), it was found that the participants use social media to communicate, have a good time and make friends. In a study conducted by Togay et al. (2013), it was revealed that the participants use social networking sites most to have contact with their friends. These findings are similar to the findings of the current study.

Half of the participants (50.7\%) have positive opinions about social media. Argin (2013) also reported that students tend to develop positive opinions about social media. The participants of the study by Togay et al. (2013) stated that the use of social media tools is necessary and useful. These findings concur with the findings of the current study. Nearly one fourth (24.1\%) of the participants expressed negative opinions about social media. Some of the participants $(22.2 \%)$ stated both negative and positive opinions about social media. The participants' opinions about social media vary depending on the gender and grade level variables. The male students expressed more positive opinions about social media than the female students. According to some participants social media is not suitable for children (20.8\%). The reasons stated for this are that contents not suitable for children are shared in social media, environments in social media are bad for children, encourage people to do bad things, it is a waste of time, it prevents people from communicating in real life and it gives useless information. Some participants $(10.4 \%)$ made suggestions for the restriction or closure of social media. Though the families of some participants want social media to be restricted (14\%), they go on using social media. Taylan and Işık (2015) stated that playing games in social media leads to internet addiction and at the same time to social media addiction. According to Taylan and Işık (2015), individuals frequently getting connected to the Internet are under the risk of addiction. Internet addiction is not related to frequent use of the Internet rather seeing the Internet as an indispensable part of one's life. The findings of the current study show that a significant part of the participants sees social media as an indispensable element in their lives. Some of the participants stated they do not spare enough time for their families and beloved ones due to social media. Some of the participants stated that playing in the street is more enjoyable than playing in social media environments. Moreover, some participants stated that they do not use social media as they are afraid that they can be addicted to social media and that they cannot spare enough time for their friends and families. Baran (2014) also found that the students spending too much time on social media allocate less time to studying outside the school and to cultural and sports activities. In this connection, the findings of the current study are similar to the findings of other studies. Some participants are of the opinion that social media is very useful while some others think that it is harmful. Thus, its use needs to be restricted.

\section{Acknowledgments}

According to the findings of this study, the majority of secondary school students use social media. Facebook and YouTube are the most used social media accounts by students. Participants often use social media, for entertainment, communicate, learning of information, spending time and study. The findings of the current study revealed that more than half of the students like social media. Therefore, social media can be used for formal and informal education. Teacher can establish social sharing groups to exchange information about their courses; thus, social media can be involved in education. Moreover, some of the students stated that they find social media harmful and they are addicted to social media. In this regard, seminars and conferences can be held at schools about social media use and social media literacy with the cooperation of teachers and parents by considering the opinions of experts. Students can be taught how to use social media correctly and effectively.

\section{References}

Altunbas, F. (2014). Yeni medya üzerine yeni iletişim teknolojileri, In M. Demir (Ed.), Sosyal Medyaya Genel Bir Bakış (pp. 45-62). Istanbul: Literatür Türk Academia.

Argın, F.S.(2013). Ortaokul ve lise öğrencilerinin sosyal medyaya ilişkin tutumlarının incelenmesi (Çekmeköy örneği) (Unpublished master's thesis). Yeditepe University/Graduate School of Social Sciences, Istanbul.

Baran, P. (2014). Sosyal medyanın eğitim süreci üzerindeki etkisi (Unpublished master's thesis). Dicle University/Graduate School of Social Sciences, Diyarbakır.

Bayraktar, R. (2013). Sosyalleşme sürecinde 14-18 yaş grubu ortaöğretim öğrencilerinin sosyal medya kullanım eğilimleri ve alı̧̧kanlıkları: Kayseri ili örneği (Unpublished master's thesis). Atatürk University/Graduate School of Social Sciences, Erzurum.

Büyüköztürk, Ş. (2011). Sosyal bilimler için veri analizi el kitabl-istatistik, araştırma deseni, spss uygulamaları ve yorum (15th ed.). Ankara: Pegem Academy

Büyükşener, E. (2009), Türkiye'de sosyal ağların yeri ve sosyal medyaya bakış, XIV. Türkiye'de İnternet 
Konferansı Bildirileri 12-13 Aralık 2009 Bilgi University, Istanbul.

Crowley, D., \& Heyer, P. (2014). The media of early civilization. in communication in history/technology-culture-society. First Edition, 2007. (Translating into Turkish: Berkay Ersöz). Ankara: Siyasal

Değirmencioğlu, G. (2014). Yeni Medya Çağında Haberciliğin Dönüşümü: Yurttaş Gazeteciliği Bağlamında Hiper Yerel Gazetecilik. M. Demir (Ed.), Konya: Literatürk.

Dikme, G. (2013). Üniversite öğrencilerinin iletişimde ve günlük hayatta sosyal medya kullanım alışkanlıkları: Kadir Has Üniversitesi örneği (Unpublished master's thesis). Kadir Has University/Graduate School of Social Sciences, Istanbul.

Eren, F., Çelik, İ., \& Aktürk, A. O. (2014). Ortaokul öğrencilerinin facebook algısı: Bir metafor analizi (Secondary school students' perceptions of Facebook: A metaphor analysis). Kastamonu Education Journal, 22(2), 635-648.

Ersöz, S., \& Seden-Meral, P. (2011). İnternet okuryazarlığı ve dijital uçurum. In N. Türkoğlu, \& M. C. Şimşek (Eds.), Medya okuryazarliğ (pp. 227-242). Parşömen. Istanbul.

Gürültü, E. (2016). Lise öğrencilerinin sosyal medya bağımlılıkları ve akademik erteleme davranışları arasindaki ilişkinin incelenmesi (Unpublished master's thesis). Marmara University/Institute of Educational Sciences, Istanbul.

Kalsın, B. (2014). Dünya'da ve Türkiye'de internet yasası düzenlemeleri: 5651 sayılı yasadaki son değişikliklere bakış. In M. Demir (Ed.), Yeni medya üzerine vol 2 yeni iletişim teknolojileri (pp. 185-213). İstanbul: Literatür Türk Acedemia.

Karadoğan-Doruk, E. \& Çavdar, D., \& Okumuş, M. (2014). Sosyal medya kullanıcılarının sanal ve gerçek hayattaki protestolara katılma durumlarının karşılaştırılması ve sanal protestoların kullanıcı algısı bakımından etkililiği. In M. Demir (Ed.), Yeni medya üzerine vol 2 yeni iletişim teknolojileri (pp. 243-271). Istanbul: Literatür Türk Acedemia.

Karasar, N. (2015). Bilimsel araştırma yöntemi (28th ed.). Ankara: Nobel.

Kırık, M. (2014). Sosyal medya-tv etkileşimi bağlamında twitter bazlı reyting ölçümleri. In M. Demir (Ed.), Yeni Medya Üzerine Yeni İletişim Teknolojileri (pp. 271-309). İstanbul: Literatür Türk Acedemia.

Miles, M, B., \& Huberman, A. M. (1994). Qualitative data analysis: An expanded Sourcebook (2nd ed). Thousand Oaks, CA: Sage.

Oğuz, S., \& Sözcü, U. (2016). Sosyal bilgiler öğretmen adaylarına göre sosyal medya kullanımının değerler üzerine etkisi. Journal of Turkish Studies, 11(9), 617-634. https://doi.org/10.7827/TurkishStudies.9562

Şahin, Ç. (2015). Bilimsel Araştırma Modelleri. In R. Kıncal (Ed.), Bilimsel araştırma yöntemleri (p. 191). Ankara: Nobel Akademi Publishing.

Şişman-Eren, E. (2014). Sosyal medya kullanım amaçları ölçeğinin geliştirilmesi ve bazı kişisel değişkenlere göre incelenmesi. Hacettepe University Journal of Education, 29(4), 230-243.

Solmaz, B., Tekin, G., Herzem, Z., \& Demir, M. (2013). İnternet ve sosyal medya kullanımı üzerine bir uygulama. Journal of Selcuk Communication, 7(4), 23-46.

Taylan, H. H., \& Işık, M. (2015). Sakarya'da ortaokul ve lise öğrencilerinde internet bağımlılığı. Journal of Turkish Studies, 10(6), 855-874. https://doi.org/10.7827/TurkishStudies.8286

Togay, A., Akdur, T. E., Yetişken, İ. C., \& Bilici, A. (2013). Ĕgitim süreçlerinde sosyal ağların kullanımı: Bir myo deneyimi (XIV). Akademik Bilişism Konferans1, 28-30 January. Antalya.

Yıldırım, A., \& Şimşek, H. (2013). Sosyal bilimlerde nitel araştırma yöntemleri. Ankara: Seçkin.

Yüksel, O. (2017). Youtube ve video blog rehberi. Ankara: Nirvana.

\section{Note}

Note 1. A part of this study has been presented as an oral presentation in the International Symposium of Education and Culture I-SASEC 2018. 


\section{Copyrights}

Copyright for this article is retained by the author(s), with first publication rights granted to the journal.

This is an open-access article distributed under the terms and conditions of the Creative Commons Attribution license (http://creativecommons.org/licenses/by/4.0/). 